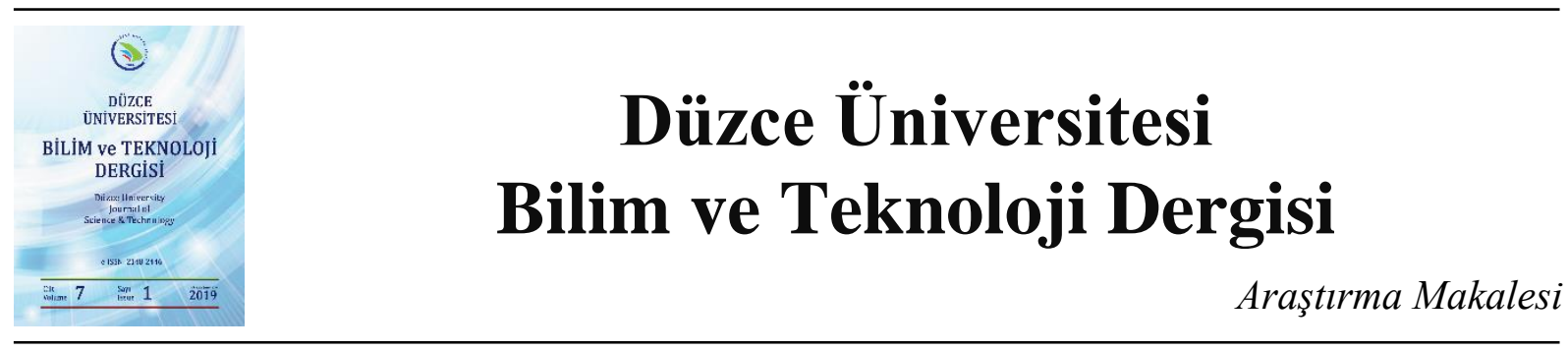

\section{Taşıma Gücü Zayıf Zeminde İnşa Edilmiş Betonarme Bir Binanın Performans Analizi}

\author{
Tuncay KAP a,", Ercan ÖZGAN ${ }^{\text {b }}$, Metin Mevlüt UZUNOĞLU ${ }^{\mathrm{c}}$ \\ a,* Düzce Üniversitesi, Düzce Meslek Yüksekokulu, İnşaat Bölümü, 81010, Düzce, Türkiye \\ ${ }^{b}$ Düzce Üniversitesi, Sanat, Tasarım ve Mimarlık Fakültesi, Mimarlı Bölümü, 81600, Düzce, Türkiye \\ ${ }^{c}$ Düzce Üniversitesi, Teknoloji Fakültesi, Inş̧aat Mühendisliği Bölümü, 81620, Düzce, Türkiye \\ *Sorumlu yazarin e-posta adresi: tuncaykap@duzce.edu.tr
}

\begin{abstract}
ÖZET
Ülkemizde yaşanan depremler sonucunda Çevre ve Şehircilik Bakanlığı, Yapıların Tasarım ve Yapım Kuralları içeren yönetmelik ve standartlarda değişiklikler yaparak Depreme dayanıklı yapılar inşa edilmesini hedeflemektedir. Bu kapsamda 2007 yılında "Deprem Bölgelerinde Yapılacak Binalar Hakkında Esaslar" yönetmeliğini yayınlamıştır. Yönetmelikte, mevcut binaların zemin özelliklerinin nasıl belirleneceği belirtilmiştir. Bu kapsamda, zemin grupları taşıma gücü açısından en yüksekten en düşüğe doğru A, B, C, D olarak tanımlanmıştır. Yerel zemin sınıfları ise zeminin en üst tabaka kalınlığı ve zemin grubuna göre Z1, Z2, Z3 ve Z4 olarak tanımlanmıştır. Yönetmeliğe göre mevcut ya da yeni yapılacak binalarda zemin etüt raporlarının düzenlenmesi istenmektedir. Bu çalışmada, 1999 Düzce depremlerine maruz kalmış ve taşıma gücü güçlü bir zemin üzerine inşa edilmiş bir okul binasının performans analizi yapılmıştır. Binasındaki taşıyıcı elemanların kapasitelerinin belirlenmesi ve deprem dayanımlarının değerlendirilmesi için eleman detayları, boyutları, taşıyıcı sistem geometrisi ve malzeme özellikleri detaylı olarak incelenmiştir. Binanın içinde ve dışında temel muayene çukurları açılarak temel şekli ve boyutları belirlenmiştir. Zeminin mühendislik özelliklerini belirlemek için jeofizik ölçümlerle birlikte 3 adet sondaj kuyusu açılmıştır. Zeminden alınan numuneler üzerinde deneyler yapılmış, zeminin "B grubu ve Z1 zemin sınıfında" olduğu belirlenmiştir. Yapının taşıyıcı elamanlarında donatı tespiti, pas payı durumu ve donatı çapları belirlenmiş ve beton karot numuneleri alınmışıı. Binanın mimari projeleri çizilmiş ve elde edilen verilerle binanın 2007 ve 2018 yönetmeliklerine göre "STA4-V14.1" paket programı ile performans analizi yapılarak değerlendirilmiştir.
\end{abstract}

Anahtar Kelimeler: Deprem, Zemin taşıma gücü, Performans analizi

\section{Performance Analysis of a Reinforced Concrete Building on the Weak Carry Load Capacity Soil}

\author{
ABSTRACT \\ As a result of the earthquakes in our country, the Ministry of Environment and Urbanization aims to build \\ Earthquake resistant structures by making changes in the regulations and standards including the Design and
}


Construction Rules of the Buildings. Within this scope, in 2007, "Principles on Buildings to be Constructed in Earthquake Zonese" was published.

The regulation states how to determine the floor characteristics of existing buildings. In this context, soil groups are defined as A, B, C, D from the highest to the lowest. Local floor classes are defined as Z1, Z2, Z3 and Z4 according to the top layer thickness of the floor and the soil group. According to the regulation, it is required to organize ground survey reports in existing or new buildings. In this study, the performance analysis of a school building, which was built on a strong ground with strong bearing strength, was carried out in 1999 Düzce earthquakes. In order to determine the capacities of the carrier elements in the building and to evaluate the earthquake resistance, element details, dimensions, structural geometry and material properties were investigated in detail. The basic shape and dimensions were determined by opening the basic inspection pits inside and outside the building. In order to determine the engineering properties of the soil, 3 boreholes were opened with geophysical measurements. Experiments were performed on the samples taken from the ground and the floor was determined as "B group and Z1 soil class Z. Reinforcement fastenings, rust share and reinforcement diameters were determined and concrete core samples were taken. The architectural projects of the building were drawn and the performance data were analyzed with STA4-V14.1 package program according to the 2007 and 2018 regulations of the building.

Keywords: Earthquake, Ground bearing strenght, Analysis of performance

\section{$\underline{\text { I. GiRis }}$}

$\mathrm{D}$ eprem Bölgelerinde Yapılacak Binalar Hakkında Esaslar Yönetmeliği’nin (Yönetmelik) 7. Bölümündeki konular Deprem Yönetmeliği kapsamına ilk kez 2007 yılında alınmıştır. Bu bölümde mevcut bir binanın deprem performansının değerlendirilmesine yönelik olarak yapılan işlemler ele alınmaktadır. Bu işlemler mevcut bir binanın durumunu saptamak için gerekli olan saha incelemelerinin yapılması, performans hedeflerinin belirlenmesi, hesap yönteminin seçimi ve uygulanmasından oluşur. Yönetmeliğin 6. Bölümünde Deprem bölgelerinde yapılacak yeni binalar ile deprem performans1 değerlendirilecek veya güçlendirilecek mevcut binalarda zemin koşullarının belirlenmesi ayrıntılı olarak belirtilmektedir. Yönetmeliğin 7. Bölümünde deprem performans1 yetersiz olan binaların güçlendirilmesi ile ilgili hususlar tanımlanmaktadır. Binaların deprem performansı yeni bir kavramdır. Deprem performansı, "tanımlanan deprem etkisi altında bir binada oluşabilecek hasarların düzeyine ve dağılımına bağlı olarak belirlenen yapı güvenliği durumu" olarak tanımlanmaktadır. Mevcut bir binanın deprem performansının belirlenebilmesi için öncelikle binanın mevcut durumunun yeterli ölçüde bilinmesi gereklidir. $\mathrm{Bu}$ amaçla inceleme yapılacak binadan toplanacak yapısal sistem özellikleri, boyutlar, malzeme ve detaylarla ilgili bilgilerin kapsamı ve zemin parametreleri yönetmelikte ayrıntılı olarak belirtilmiştir. Zemin koşulları ile ilgili hususlar yönetmeliğin 6. Bölümünde ifade edilmiştir. Buna göre zemin etüt raporunda zeminin grupları ve yerel zemin sınıfları açık olarak belirtilecektir. Söz konusu zemin grupları aşağıdaki tabloda gösterilmiştir [Tablo1]. 
Tablo 1. Zemin Gruplart

\begin{tabular}{|c|c|c|c|c|c|}
\hline $\begin{array}{l}\text { Zemin } \\
\text { Grubu }\end{array}$ & Zemin Grubu Tanımı & $\begin{array}{l}\text { Stand. } \\
\text { Penetr. } \\
(\mathrm{N} / 30)\end{array}$ & $\begin{array}{l}\text { Relatif } \\
\text { Sıkılık } \\
(\%)\end{array}$ & $\begin{array}{l}\text { Serbest } \\
\text { Basınç } \\
\text { Direnci } \\
\text { (kPa) }\end{array}$ & $\begin{array}{l}\text { Kayma } \\
\text { Dalgası } \\
\text { Hizı } \\
(\mathbf{m} / \mathbf{s})\end{array}$ \\
\hline (A) & $\begin{array}{l}\text { 1. Masif volkanik kayaçlar ve } \\
\text { ayrışmamış sağlam metamorfik kayaçlar, } \\
\text { 2.Çok sıkı kum, çakıl, } \\
\text { 3. Çok kil ve siltli kil. }\end{array}$ & $\begin{aligned} & - \\
> & 50 \\
> & 32\end{aligned}$ & $\begin{array}{c}- \\
85-00 \\
-\end{array}$ & $\begin{array}{l}>1000 \\
- \\
>400\end{array}$ & $\begin{array}{l}>1000 \\
>700 \\
>700\end{array}$ \\
\hline (B) & $\begin{array}{l}\text { 1. Masif volkanik kayaçlar ve } \\
\text { ayrışmamış sağlam metamorfik kayaçlar, } \\
\text { 2.Çok sıkı kum, çakıl, } \\
\text { 3. Çok kil ve siltli kil }\end{array}$ & $\begin{array}{c}- \\
30-50 \\
16-32\end{array}$ & $\begin{array}{c}- \\
65-85 \\
- \\
\end{array}$ & $\begin{array}{c}500-000 \\
- \\
200-400 \\
\end{array}$ & $\begin{array}{l}700-1000 \\
400-700 \\
300-700 \\
\end{array}$ \\
\hline (C) & $\begin{array}{l}\text { 1. Masif volkanik kayaçlar ve } \\
\text { ayrışmamış sağlam metamorfik kayaçlar, } \\
\text { 2.Çok sıkı kum, çakıl, } \\
\text { 3. Çok kil ve siltli kil }\end{array}$ & $\begin{array}{c}- \\
10-30 \\
8-16 \\
\end{array}$ & $\begin{array}{c}- \\
35-65 \\
- \\
\end{array}$ & $\begin{array}{c}<500 \\
- \\
100-200 \\
\end{array}$ & $\begin{array}{l}400-700 \\
200-400 \\
200-300 \\
\end{array}$ \\
\hline (D) & $\begin{array}{l}\text { 1. Masif volkanik kayaçlar ve } \\
\text { ayrışmamış sağlam metamorfik kayaçlar, } \\
\text { 2.Çok sıkı kum, çakıl, } \\
\text { 3. Çok kil ve siltli kil }\end{array}$ & $\begin{array}{l}- \\
<10 \\
<8\end{array}$ & $\begin{array}{l}- \\
<35 \\
-\end{array}$ & $\begin{array}{c}- \\
- \\
<100\end{array}$ & $\begin{array}{l}<200 \\
<200 \\
<200\end{array}$ \\
\hline
\end{tabular}

Yerel zemin sınıfları da aşağıdaki tabloda gösterilmiştir [Tablo2].

Tablo 2. Yerel Zemin Sinıflart

\begin{tabular}{|c|c|}
\hline $\begin{array}{l}\text { Yerel Zemin } \\
\text { sınıfı }\end{array}$ & $\begin{array}{c}\text { Yerel zemin grubu ve en } \\
\text { üst zemin tabakası kalınlığı }\left(\mathrm{h}_{1}\right)\end{array}$ \\
\hline $\mathrm{Z1}$ & $\begin{array}{c}\text { (A)Grubu zeminler } \\
\mathrm{h} 1 \leq 15 \text { m olan }(\mathrm{B}) \text { grubu zeminler }\end{array}$ \\
\hline $\mathrm{Z} 2$ & $\begin{array}{l}\text { h1 }>15 \text { m olan }(B) \text { Grubu zeminler } \\
\text { h1 } \leq 15 \text { m olan }(C) \text { grubu zeminler }\end{array}$ \\
\hline Z3 & $\begin{array}{l}\text { h1 }>15 \text { m olan }(B) \text { Grubu zeminler } \\
\text { h1 } \leq 15 \text { m olan }(C) \text { grubu zeminler }\end{array}$ \\
\hline $\mathrm{Z4}$ & $\begin{array}{l}\text { h1 }>15 \text { m olan }(B) \text { Grubu zeminler } \\
\text { h1 } \leq 15 \text { m olan }(C) \text { grubu zeminler }\end{array}$ \\
\hline
\end{tabular}

Zemin etüt raporundan elde edilen veriler ışığında binanın malzeme bilgileri kullanılarak yapısal modeli oluşturulur ve deprem etkileri altında elemanlarda meydana gelecek iç kuvvetler ve şekil değiştirmeler hesaplanır [1]. Mevcut binalarda alt yapının durumu üst yapıdan farklı değildir. Temellerdeki betonların ayrıştığı, bağ kirişlerinin yeterli olmadığı, donatıların korozyona uğradığı, ilk yapım sırasında yeteri kadar temel alanının yapılmadığı anlaşılmıştır $[2,3,4,5,6,7,8,9,10,11,12,13,14,15,16,17]$. 


\section{MATERIALS AND METHOD}

Bu çalışmada Yeni Taşköprü okul binası 1997 yılında 1975 yönetmeliğine uygun olarak inşa edilmiştir. Binanın taşıyıcı sistem elemanlarının taşıma kapasitelerinin belirlenmesi, deprem dayanımlarının bulunmasında kullanılacak eleman detayları ve boyutları, taşıyıcı sistem geometrisi ve malzeme özellikleri detaylı olarak incelenmiştir. Okul binasının taban alanı 614,50 $\mathrm{m} 2$ olup yapı, zemin ve normal kattan oluşmaktadır [Şekil 1].

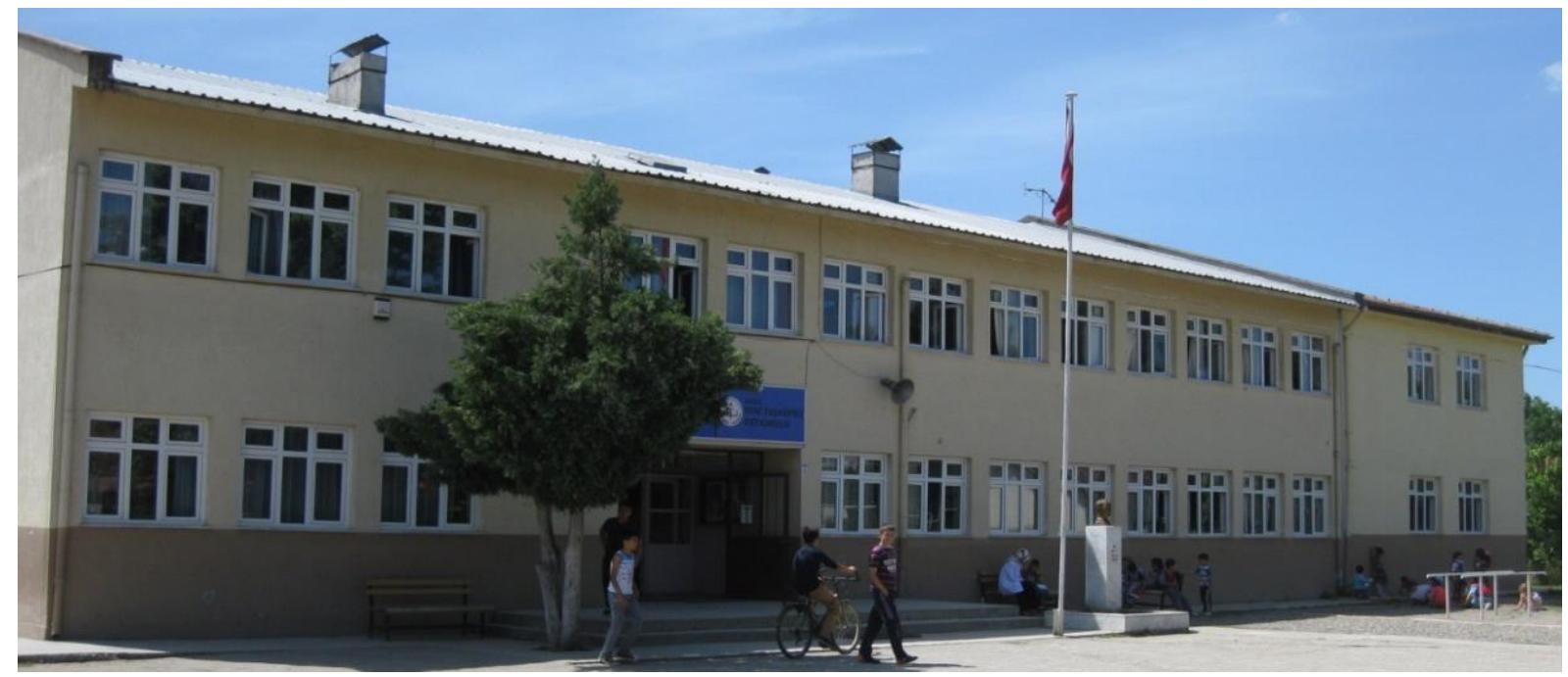

Şekil 1. Yeni Taşköprü Illk Okulu girişs cephe görünümü

Zemin Etüt Raporundan Okul binasının dış tarafında ve içinde açılan muayene çukurlarından temel derinliği $\mathrm{Df}=1,3 \mathrm{~m}$ ve temel genişliği $\mathrm{B}=1,80 \mathrm{~m}$ olarak ölçülmüştür. Zemin Etüt Raporunda, incelenen binanın zemininde 2 adet $1,35 \mathrm{~m}$ ve 1 adette $15,0 \mathrm{~m}$ derinlikte olmak üzere toplam 3 adet sondaj yapılmıştır. İncelenen binanın taşıyıcı sistemine ait statik projeleri bulunamamıştır. Bina betonarme karkas olup binada yapılan röleve çalışmalarından sonra kat planları çizilmiş ve taşıyıcı eleman boyutları ölçülerek statik projeleri hazırlanmıştır. Binanın içinde ve dışında zemin muayene çukurları açılarak temel yapısı, temel özellikleri ve yer altı su seviyesi gibi parametreler belirlenmiştir. Yapının temel özelliklerinin belirlenebilmesi amacı ile binanın içinden ve dışından temel çukurları açılarak temelin boyutları, temel derinliği ve temel şekli belirlenmiştir [Şekil 2].
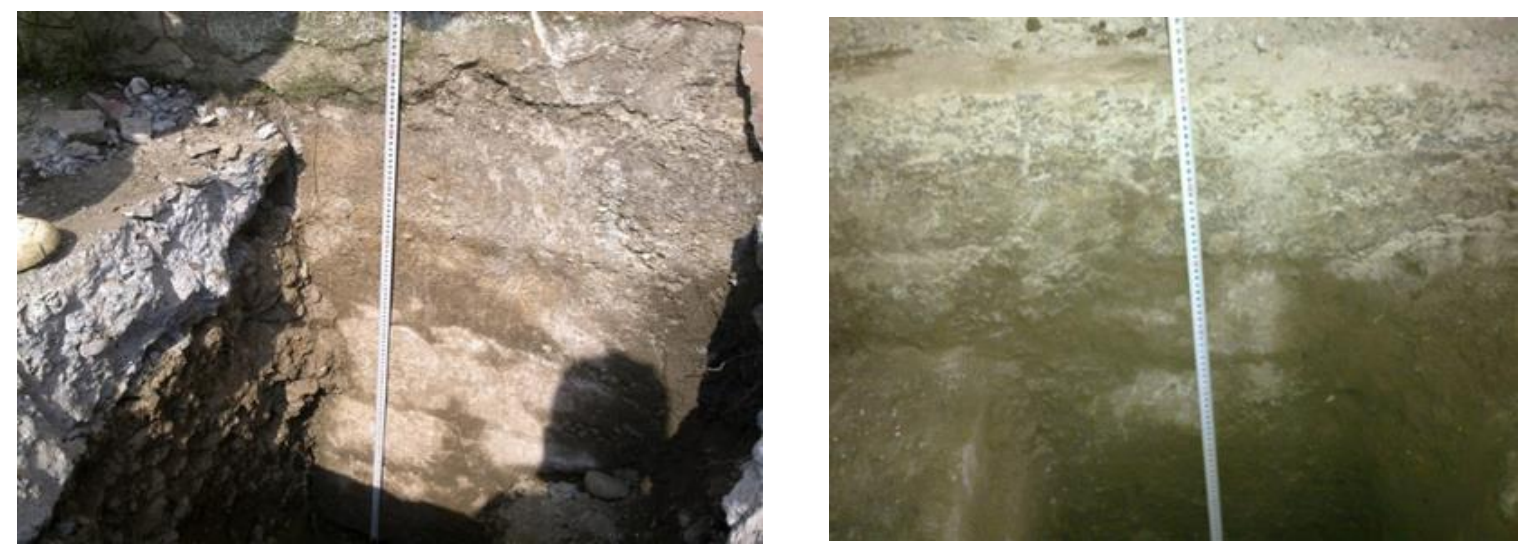

Şekil 2. Binanın dışından ve içinden açılan temel çukurları 
Yapılan sondajlarda her 1,5 m'de bir SPT deneyi yapılmış ve $1.0 \mathrm{~m}$ ile $2.0 \mathrm{~m}$ arasındaki derinliklerden drenajsız üç eksenli basınç deneyi için karot numuneleri alınmıştır. Sondaj çalışmalarında yer altı su seviyesinin $3.0 \mathrm{~m}$ olduğu belirtilmiştir. SPT deney sonuçları incelendiğinde; SK2 ve SK3 kuyularında SPT değerlerinin 12,5 m'ye kadar SK1 kuyusunda ise SPT değerlerinin 15,0 m' ye kadar ölçülebildiği anlaşılmıştır. Zemin etüt raporuna göre SK1 kuyusunda 15,0 m derinlik boyunca ortalama SPT-N60 değerinin 14, SK2 kuyusunda 13,5 m derinlik boyunca ortalama SPT-N60 değerinin 9 ve SK3 kuyusunda 13,5 m derinlik boyunca ortalama SPT-N60 değerinin de 11 olduğu görülmüştür. Temel derinliğinin $\mathrm{Df}=1.30 \mathrm{~m}$ ve temel genişliğinin $\mathrm{B}=1.80 \mathrm{~m}$ olduğu dikkate alındığında incelenen zemin için anlamlı derinlik $\mathrm{H}=\mathrm{Df}+2 \mathrm{~B}$ ' den 4.90 m olarak hesaplanmıştır. Bu durumda SPT-N60 değerleri olarak 4,90 ya da 5,0 m derinlik içindeki SPT-N60 değerlerinin ortalaması alınarak zemin emniyet gerilmesi hesaplanabilir.

\section{BULGULAR}

Yapının 2007 ve 2018 deprem yönetmeliklerine uygunluğunun analiz edilebilmesi için yönetmelik kapsamında betonarme elemanlardan beton karot numuneler alınmıştır. Binanın temel ve her kattan 3'er adet olmak üzere toplamda 9 adet karot numune alınmıştır [Şekil 3].
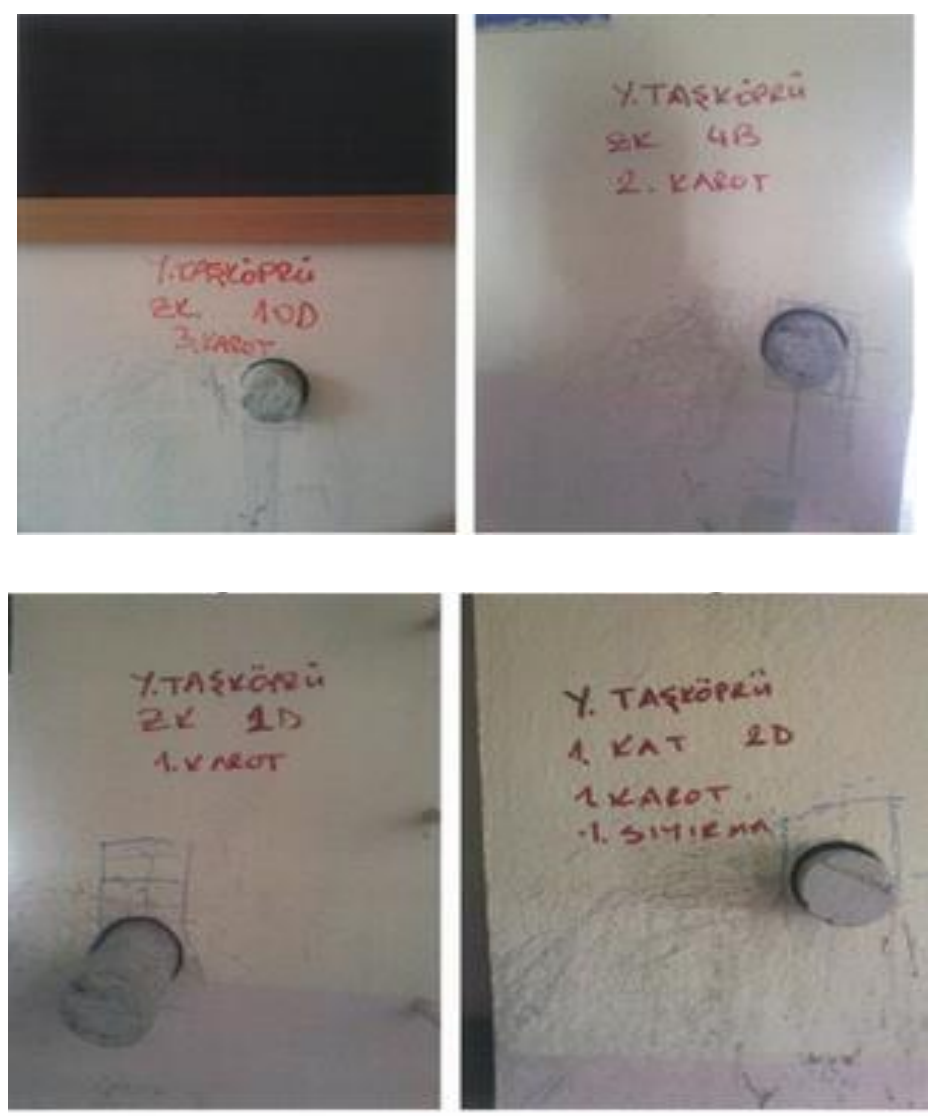

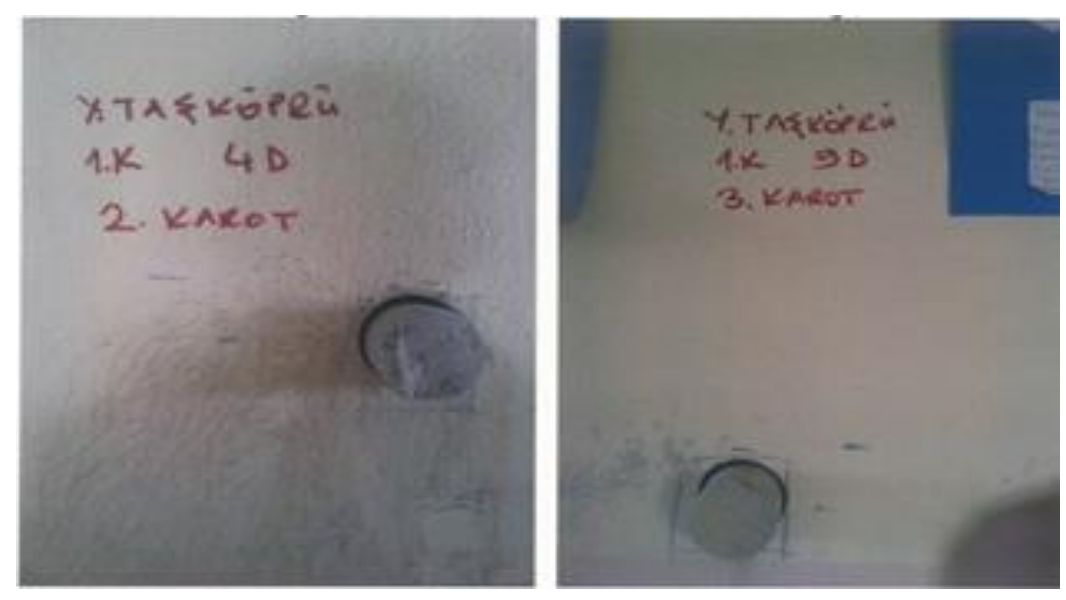

Şekil 3. Binadan karot numuneleri alınmast

Karot numuneler TS-EN 12504-1, TS EN 12390-3 standartlarına göre alınmış olup, hesaplamalar TS EN 13791 standardına göre yapılmıştır. Deneyler sonucu elde edilen beton basınç dayanımları aşağıda verilmiştir [Tablo 3].

Tablo 3. Karot numunelerin basınç dayanımları

\begin{tabular}{c|l|c}
\hline $\begin{array}{c}\text { Numune } \\
\text { No }\end{array}$ & Alındı̆̆ yer & $\begin{array}{c}\text { Basınç değeri } \\
\left(\mathrm{N} / \mathrm{mm}^{2}\right)\end{array}$ \\
\hline 1 & Temel 1 & 19.64 \\
\hline 2 & Temel 2 & 21.38 \\
\hline 3 & Temel 3 & 22.62 \\
\hline 4 & Zemin Kat Kolon 1 & 21.22 \\
\hline 5 & Zemin Kat Kolon 2 & 15.06 \\
\hline 6 & Zemin Kat Kolon 3 & 13.30 \\
\hline 7 & 1. Kat Kolon 1 & 34.43 \\
\hline 8 & 1. Kat Kolon 2 & 21.13 \\
\hline 9 & 1. Kat Kolon 3 & 25.57 \\
\hline & F $_{\text {min } \text { Minimum Mukavemeti }}$ & 13.30 \\
\hline & $F_{\text {ort }}$ Ortalama Mukavemet & 21.59 \\
\hline
\end{tabular}

Binanın betonarme taşıyıcı elemanlardaki donatı sayısı ve donatı çaplarının belirlenebilmesi amacıyla bu elemanların yüzeyinde sıyırma işlemleri yapılmıştır [Şekil 4].

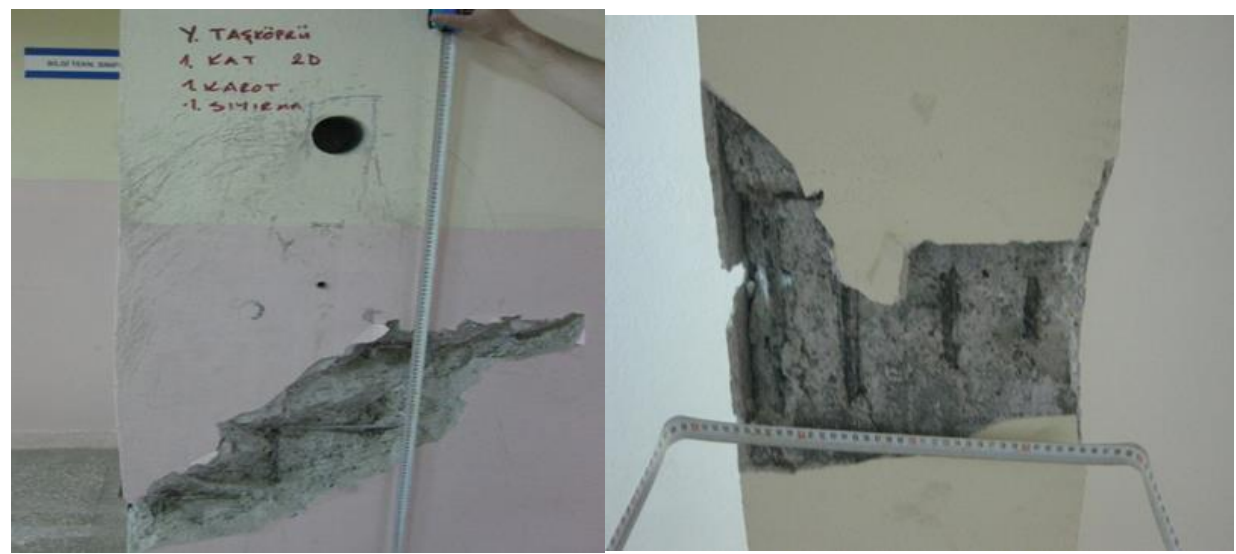




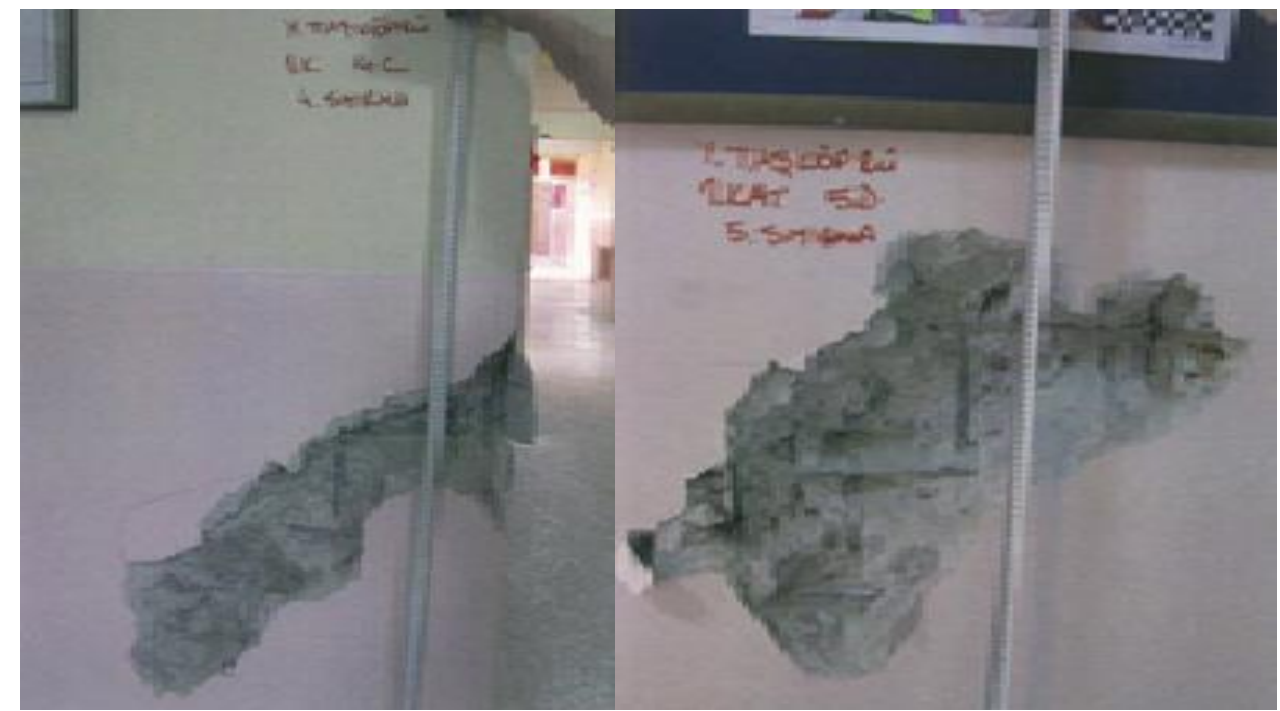

Şekil 4. Kolonlarda sıyırma işlemi yapılmasl.

Sıyırma yapılmayan kolon, kiriş, perde gibi betonarme elemanlardaki donatıların sayısı ve çaplarının tespiti amacıyla da donatı tespit cihazları ile donatı tespitleri yapılarak incelenen yapının malzeme özellikleri belirlenmiştir [Şekil 5].
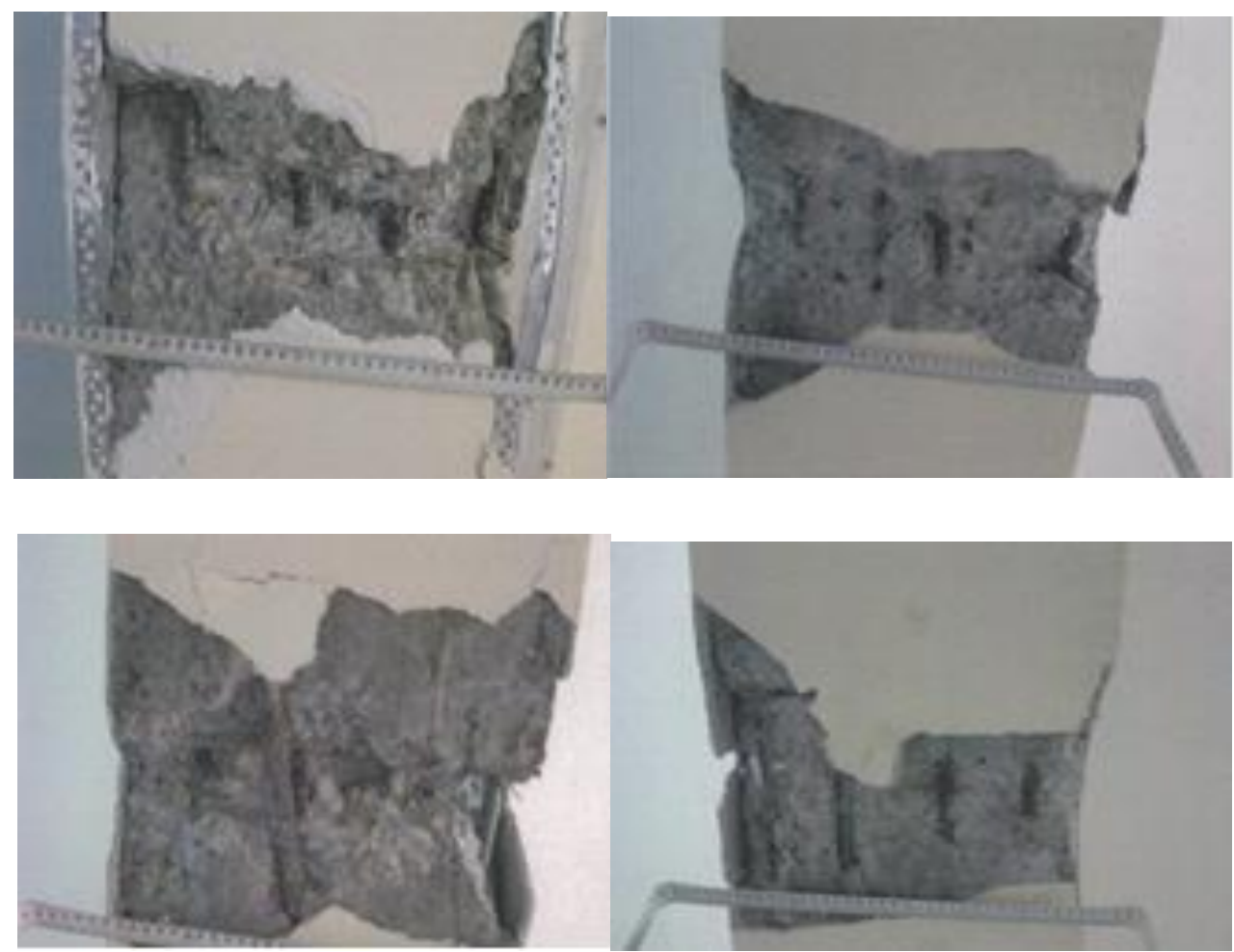

Şekil 5. Kirişlerde slyırma işlemi yapılması. 
Sıyırma yapılmayan kolon, kiriş, perde gibi betonarme elemanlardaki donatıların sayısı ve çaplarının tespiti amacıyla da donatı tespit cihazları ile donatı tespitleri yapılarak incelenen yapının malzeme özellikleri belirlenmiştir [Şekil 3].

Sıyırma yapılmayan kolon, kiriş, perde gibi betonarme elemanlardaki donatıların sayısı ve çaplarının tespiti amacıyla da donatı tespit cihazları ile donatı tespitleri yapılarak incelenen yapının malzeme özellikleri belirlenmiştir [Şekil 6].

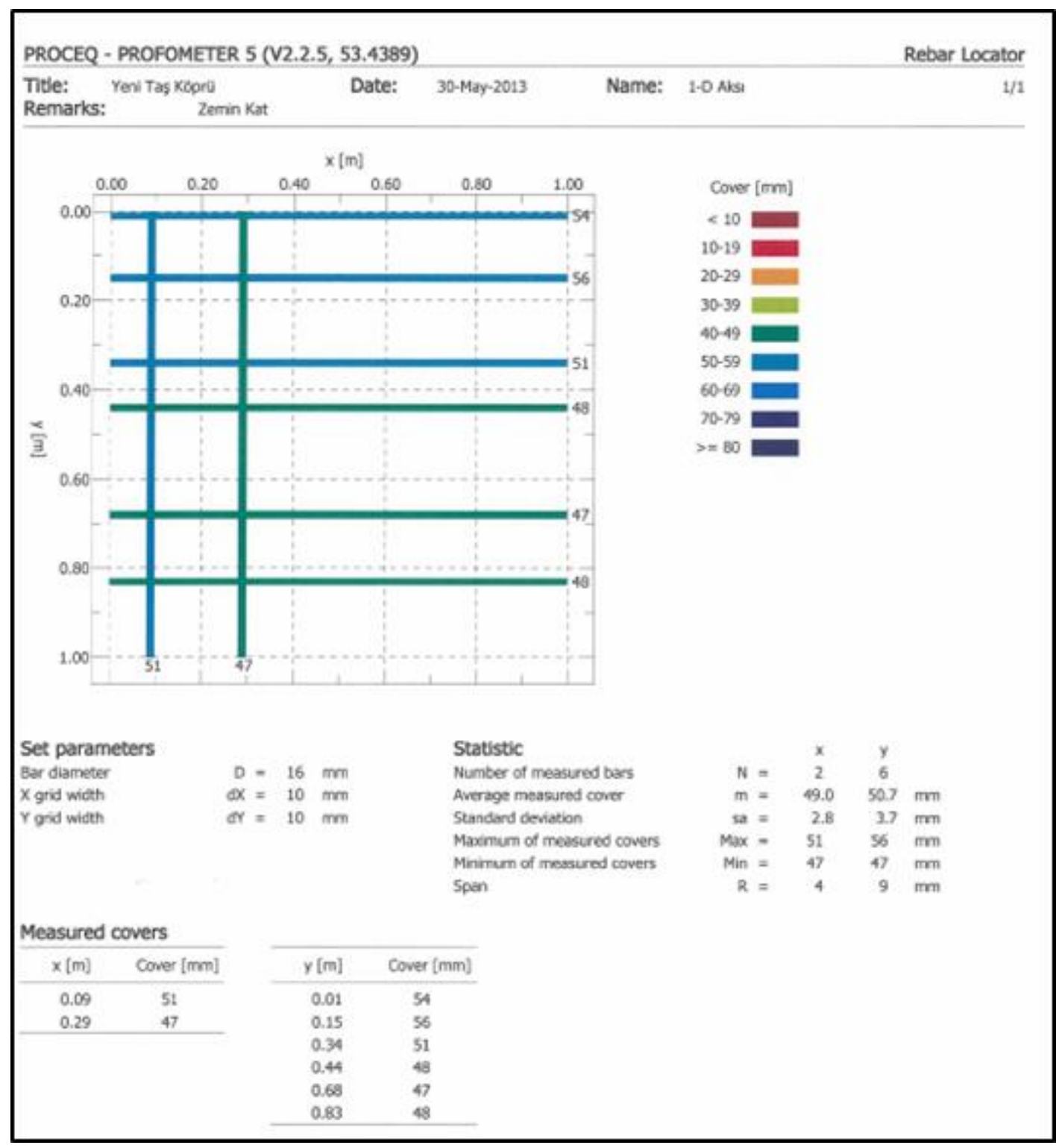

Şekil 6. Binanın 2. Katında Profometer Cihazı ile Donatı Tespiti

İncelenen yapının tüm katlarında sıyırma yapılan betonarme elemanlardaki donatılar tespit edilerek tablo haline getirilmiştir [Tablo 4]. 
Tablo 4. Katlara Göre Slyırma Yapılan Betonarme Elemanlar ve Donatı Durumları

\begin{tabular}{|c|c|c|c|c|c|c|c|c|c|c|c|c|}
\hline & \multicolumn{11}{|c|}{ DONATI SIYIRMA TESPIT FORMU } \\
\hline & & \multicolumn{4}{|c|}{ Okulun Adı / Binası } & \multicolumn{7}{|c|}{ YENI TAŞ KÖPRÜ İÖO } \\
\hline & & \multicolumn{4}{|l|}{ Tarih } & \multicolumn{7}{|c|}{$26 . .06 . .2013$} \\
\hline & & \multicolumn{4}{|c|}{ Yapım şekli } & \multicolumn{3}{|c|}{ Betonarme Karkas } & $\square$ & \multicolumn{2}{|c|}{ Betonarme Yığma } & \multirow[b]{2}{*}{$\begin{array}{l}\text { Çatı K : } \\
\text { yok }\end{array}$} \\
\hline & & \multicolumn{4}{|c|}{ Kat sayısı } & \multicolumn{2}{|c|}{ Bodrum : X } & \multicolumn{2}{|c|}{ Zemin : 1} & \multicolumn{2}{|l|}{ Normal : 1} & \\
\hline \multirow[t]{3}{*}{$\mathrm{S} N$} & \multirow{2}{*}{$\begin{array}{c}\text { Elemanı } \\
\mathrm{n} \text { adı }\end{array}$} & \multirow{2}{*}{$\begin{array}{c}\text { Eleman } \\
\text { Türü }\end{array}$} & \multirow{2}{*}{$\begin{array}{l}\text { Pas } \\
\text { pay1 } \\
\text { mm }\end{array}$} & \multicolumn{2}{|c|}{ Esas Donatı } & \multicolumn{2}{|c|}{ Esas Donatı } & \multicolumn{2}{|c|}{$\begin{array}{c}\text { Etriye / } \\
\text { Dağıtma } \\
\text { Donatısı }\end{array}$} & \multirow[t]{2}{*}{ Siklaştırma } & \multirow[t]{2}{*}{ Filiz } & \multirow[t]{2}{*}{ Korozyon } \\
\hline & & & & $\begin{array}{l}\text { Çap } \\
\text { mm }\end{array}$ & Adet & $\begin{array}{l}\text { Çap } \\
\text { mm }\end{array}$ & $\begin{array}{l}\text { Aralık } \\
\mathrm{cm}\end{array}$ & $\begin{array}{l}\text { Çap } \\
\text { mm }\end{array}$ & $\begin{array}{l}\text { Aral1 } \\
\mathrm{k} \mathrm{cm}\end{array}$ & & & \\
\hline & 1. Kat & & & & & & & & & & & \\
\hline 1 & 1.-D & $\mathrm{P}$ & 30 & & & 18 & 16 & 10 & 20 & & & \\
\hline 2 & $2-\mathrm{C}$ & $\mathrm{P}$ & 35 & & & 16 & 19 & 8 & 21 & & & \\
\hline 3 & $4-\mathrm{C}$ & $\mathrm{K}$ & 30 & 16 & 3 & & & 8 & 18 & & & \\
\hline 4 & $2-\mathrm{B}$ & $\mathrm{K}$ & 55 & 16 & 3 & & & 10 & 17 & & & \\
\hline 5 & 5-D & $\mathrm{K}$ & 40 & 16 & 3 & & & 10 & 20 & & & \\
\hline 6 & $6-C$ & $\mathrm{~K}$ & 45 & 16 & 3 & & & 10 & 21 & & & var \\
\hline 7 & 7-D & $\mathrm{K}$ & 55 & 16 & 3 & & & 8 & 18 & & & \\
\hline 8 & $10-\mathrm{D}$ & $\mathrm{P}$ & 40 & & & 12 & 10 & 10 & 19 & & & \\
\hline \multirow[t]{2}{*}{9} & $10-\mathrm{C}$ & $\mathrm{P}$ & 40 & & & 12 & 18 & 10 & 19 & & & \\
\hline & $\begin{array}{c}\text { Zemin } \\
\text { Kat }\end{array}$ & & & & & & & & & & & \\
\hline 10 & $1-2-\mathrm{D}$ & $\mathrm{P}$ & 25 & & & 10 & 28 & 10 & 30 & & & \\
\hline 11 & $2-\mathrm{C}$ & $\mathrm{K}$ & 35 & 14 & 3 & & & 8 & 17 & & & \\
\hline 12 & $2-B$ & $\mathrm{~K}$ & 35 & 16 & 3 & & & 8 & 20 & & & \\
\hline 13 & 4-C & $\mathrm{K}$ & 25 & 16 & 3 & & & 8 & 17 & & & \\
\hline 14 & 5-D & $\mathrm{K}$ & 50 & 16 & 3 & & & 8 & 17 & & & \\
\hline 15 & 6-C & $\mathrm{K}$ & 20 & 16 & 3 & & & 10 & 9 & & & \\
\hline 16 & 7-D & $\mathrm{K}$ & 30 & 16 & 3 & & & 8 & 15 & & var & \\
\hline 17 & 9-D & $\mathrm{K}$ & 30 & 16 & 3 & & & 8 & 10 & & & \\
\hline 18 & $10-\mathrm{C}$ & $\mathrm{P}$ & 10 & & & 14 & 21 & 10 & 10 & & & \\
\hline
\end{tabular}

Binanın inşa edildiği zeminin yatak katsayısı (k) $696 \mathrm{t} / \mathrm{m}^{3}$ ve zemin emniyet gerilmesi de (qem) 0,58 $\mathrm{kg} / \mathrm{cm}^{2}$ 'dir. SK-1, SK-2 ve SK3 sondaj kuyularında $5 \mathrm{~m}$ derinlik boyunca hesaplanan en düşük ortalama SPT-N60 değeri SK-1 kuyusunda 7 olarak hesaplanmıştır. Bu durumda incelenen okul binasının zeminin 2007 yönetmeliğinde tanımlanan zemin sınıflarından "D" zemin grubunda ve Z4 yerel zemin sınıfı olduğu söylenebilir. Bu durumda zeminin izin verilebilir taşıma gücü değeri güvenlik katsayısı Gs=3 alınırsa aşağıdaki yaklaşımlara göre hesaplanabilir. Hesaplamalarda yapının temel genişliği $\mathrm{B}$ > 1.22 olarak dikkate alınmıştır. Temel derinliği $\mathrm{Df}=1.30 \mathrm{~m}$, Temel genişliği $\mathrm{B}=1.80 \mathrm{~m}$ ve $\mathrm{kd}=1+0.33(\mathrm{D} / \mathrm{B})$ için; izin verilebilir taşıma gücü değerleri farklı yaklaşımlar için hesaplanmıştır. Buna göre;

Meyerhof (1956)' ya göre; $\mathrm{qa}=8 \mathrm{~N}[(\mathrm{~B}+0.305) / \mathrm{B})] 2 \mathrm{xkd}$ buradan $\mathrm{qa}=93,68 \mathrm{kN} / \mathrm{m}^{2}$ ve qem=31,2 $\mathrm{kN} / \mathrm{m}^{2}$ olarak ya da qem $=0.31 \mathrm{~kg} / \mathrm{cm}^{2}$ olarak hesaplanabilir.

Bowles (1988)'e göre; $\mathrm{qa}=12.5 \times \mathrm{N}[(\mathrm{B}+0.305) / \mathrm{B})] 2 \times k d$ buradan $\mathrm{qa}=146,37 \mathrm{kN} / \mathrm{m}^{2}$ ve $\mathrm{qem}=48,79 \mathrm{kN} / \mathrm{m}^{2}$ olarak ve qem $=0.49 \mathrm{~kg} / \mathrm{cm}^{2}$ olarak hesaplanabilir. 
Terzaghi ve Peck (1967)'ye göre;

$\mathrm{qa}=\mathrm{N} / 0.08[(\mathrm{~B}+0.3) / \mathrm{B})] 2 \mathrm{xkd} \quad$ buradan

$\mathrm{qa}=146,26 \mathrm{kN} / \mathrm{m}^{2}$ ve $\mathrm{qem}=48,75 \mathrm{kN} / \mathrm{m}^{2}$ olarak ve qem $=0.49 \mathrm{~kg} / \mathrm{cm}^{2}$ olarak hesaplanabilir.

Yukarıdaki hesaplamalar dikkate alındığında incelenen okul binanın zemin yatak katsayısı Bowles 1988'e göre $\mathrm{Ks}=400 x q a$ ' dan $\mathrm{ks}=370 \mathrm{kN} / \mathrm{m}^{3}$ ile $588 \mathrm{kN} / \mathrm{m}^{3}$ olarak hesaplanabilir.

İncelenen zeminin sismik verileri dikkate alınarak zeminin emniyet gerilmeleri ve taşıma gücü değerleri, temel genişlikleri ile temel derinliğine bağlı olarak değerlendirildiğinde;

- Temel genişliği $1.2 \leq \mathrm{B} \leq 3.0 \mathrm{~m}$ için zemin emniyet gerilmesi değerinin 1 . Tabaka için $2.78 \mathrm{~m}$ derinlikte $0.57 \mathrm{~kg} / \mathrm{cm}^{2}$ ile minimum değerde olduğu, $3.80 \mathrm{~m}$ derinlikte ise $0.59 \mathrm{~kg} / \mathrm{cm}^{2}$ ile maksimum olduğu, 2. Tabakada ise $2.78 \mathrm{~m}$ derinlikte $0.87 \mathrm{~kg} / \mathrm{cm}^{2}$ ile minimum değerde olduğu, $3.80 \mathrm{~m}$ derinlikte ise $0.90 \mathrm{~kg} / \mathrm{cm}^{2}$ ile maksimum değerde olduğu anlaşılmıştır.

- Jeofizik verilerinin sonuçlarına göre incelenen zeminin dinamik düşey yatak katsayısı 1 . Tabaka için ortalama $764 \mathrm{t} / \mathrm{m}^{3}$ hesaplanmış olup ko=500-1000 t/m $\mathrm{m}^{3}$ aralığında alınması önerilmiştir. 2. Tabaka için ise zeminin yatak katsayısı ortalama $1172 \mathrm{t} / \mathrm{m}^{3}$ olarak hesaplanmış ve 2 . Tabaka için $\mathrm{ko}=750-1500 \mathrm{t} / \mathrm{m}^{3}$ aralığında alınması önerilmiştir. Zeminde meydana gelebilecek oturma miktarı ise jeofizik verilerine göre 1. Tabaka için max. $2.83 \mathrm{~cm}$ ve 2. Tabaka için ise max.0.93 $\mathrm{cm}$ olarak hesaplandığı ifade edilmiştir. Jeofizik verilerine bağlı olarak incelenen zeminin 1. Tabaka için tabaka kalınlığı ortalaması 3.37 m olup Zemin Grubu D, Yerel Zemin Sınıfı Z4 olarak, 2. Tabaka için ise Zemin Grubu C ve Yerel Zemin Sınıfının da Z4 olarak değerlendirildiği belirtilmiştir. Yapılan sondaj çalışmalarında ise Yeraltı Suyunun 3,0 m derinlikte olduğu ifade edilmiştir.

- Mekanik ve sismik çalışmalar birlikte değerlendirildiğinde sismik çalışma sonuçlarının da dikkate alınması gerektiği ve her ne kadar zemin emniyet gerilmesi için sismik ve mekanik deneylerin ortalaması alınarak qem $=0.84 \mathrm{~kg} / \mathrm{cm}^{2}$ olarak alınması önerilmiştir. Ancak SPT-N60 deney sonuçları, Terzaghi taşıma gücü hesap sonuçları ve sismik analiz sonuçları bir bütün olarak değerlendirildiğinde güvenli bölgede kalmak amaciyla Zemin Emniyet Gerilmesinin qem $=0.50 \mathrm{~kg} / \mathrm{cm}^{2}$ olarak alınmasının daha uygun olacağı düşünülmektedir.

- Zemin yatak katsayısı ise $\mathrm{ks}=500-1000 \mathrm{ton} / \mathrm{m}^{3}$ arasında önerilmiş olmakla birlikte güvenli kısımda kalmak amacıyla zeminin yatak katsayısının 500 ton $/ \mathrm{m}^{3}$ olarak alınmasının uygun olacağı düşünülmektedir. Zemin Etüt Raporunda, incelenen zeminin D Zemin Grubunda ve Z4 Yerel Zemin Sınıfında olduğu belirtilmiştir. Zeminin heterojen özellikte olması nedeniyle yerinde yapılacak başka incelemeler sonucunda belirlenecek değerlerde dikkate alınarak nihai karar verilebilir. Binanın zemin etüdü ve röleve çalışmaları sonucunda mimari projesi hazırlanmıştır [Şekil 5]. 


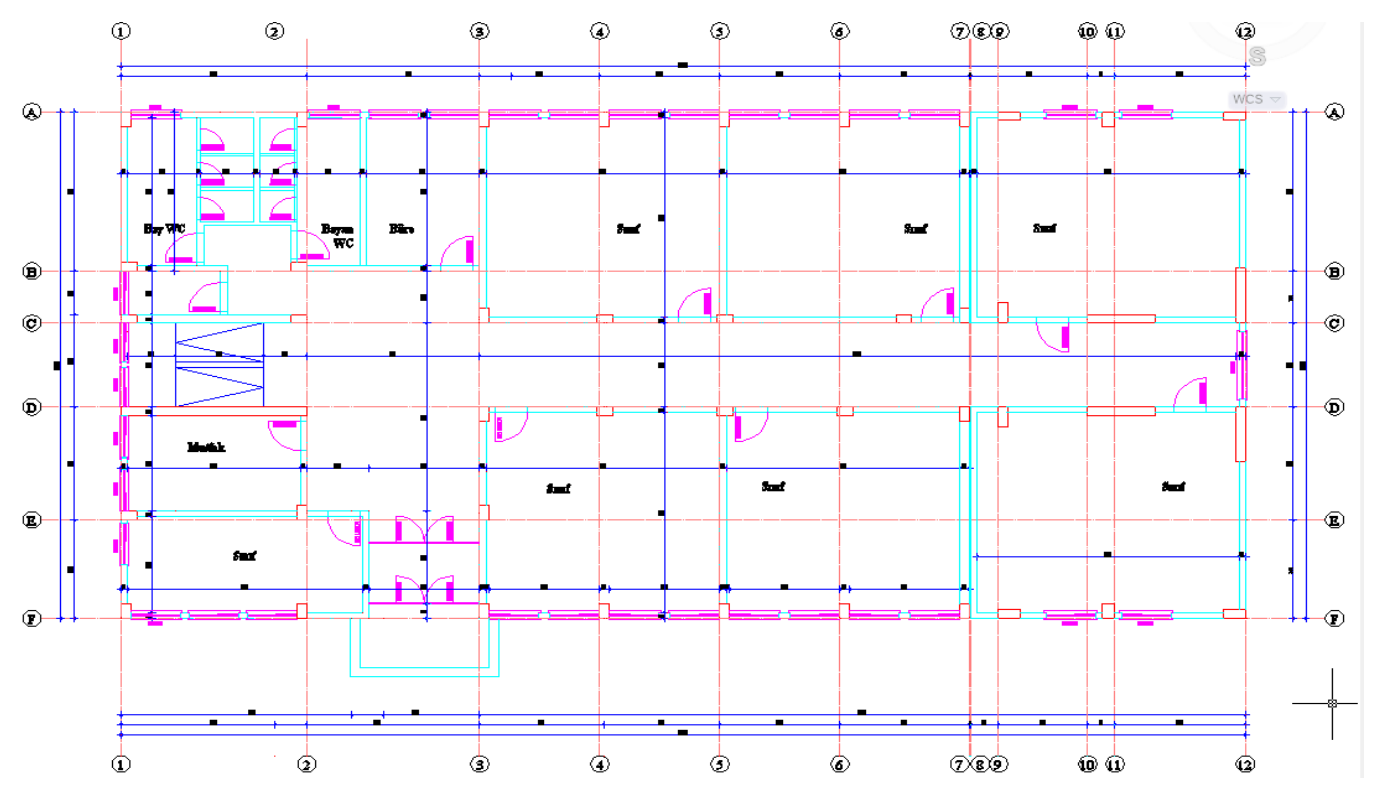

Şekil 5. Taşköprü Illkokul Binası Zemin Kat Planı

2007 Deprem yönetmeliği açısından Performans Analizi yapılan İlkokul Binasının Temel aplikasyon planı [Şekil 6] ve kalıp teçhizat planı örneği için 1. kata ait kalıp teçhizat planı verilmiştir [Şekil 7].

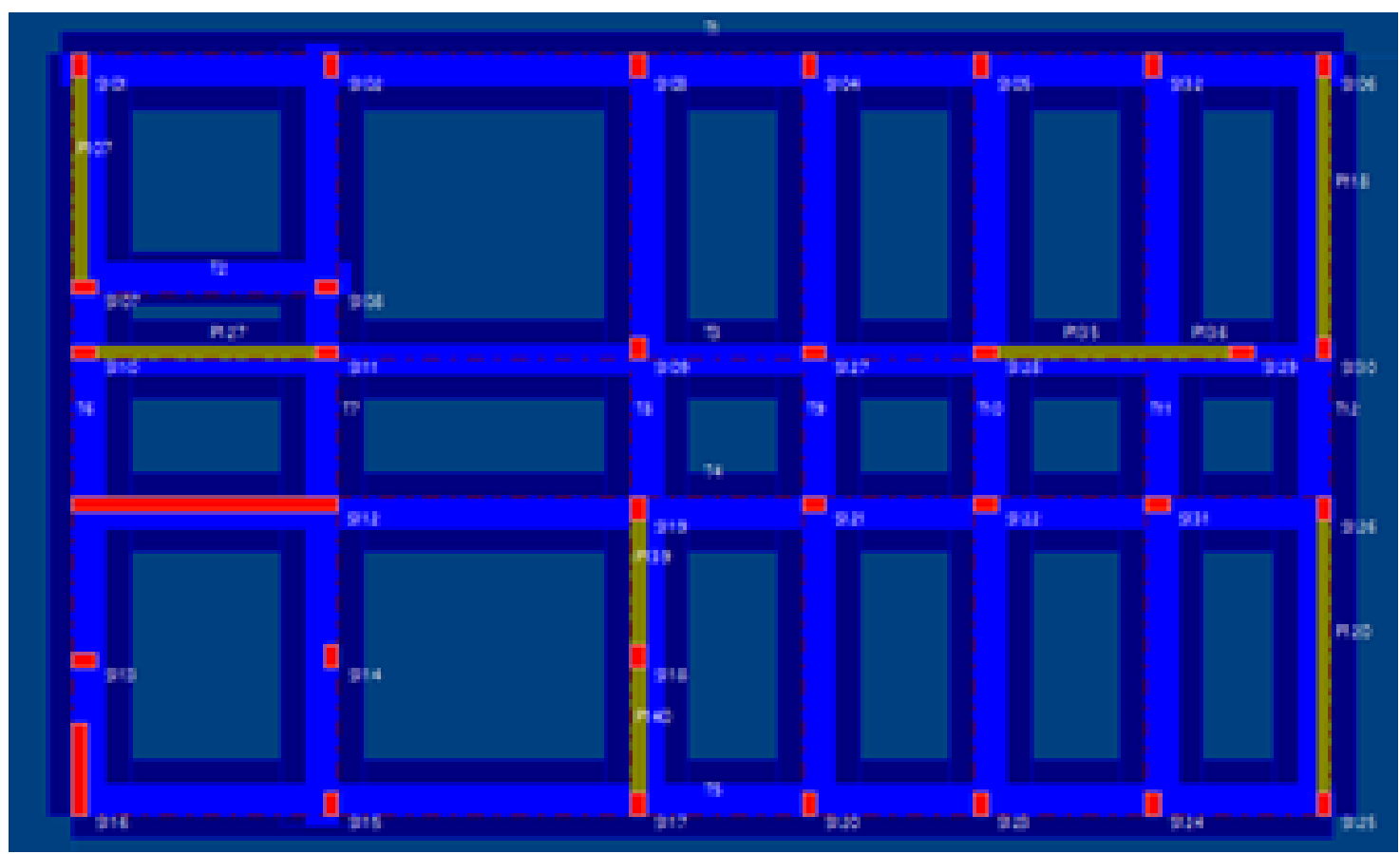

Şekil 6. Taşköprü İlkokul Binası Temel Kalıp Planı 


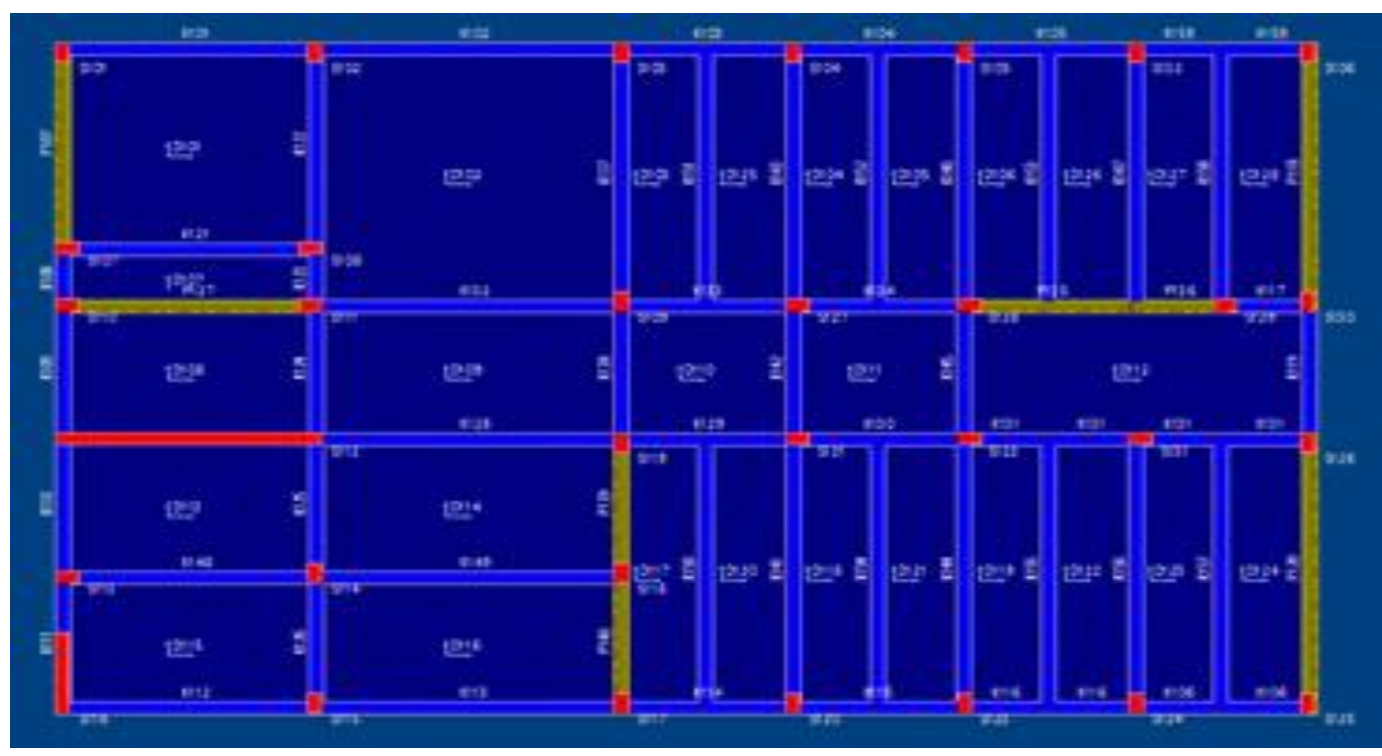

Şekil 7. Taşköprü İlkokul Binası Zemin Kat Kalıp Planı

\section{PERFORMANS ANALIZI}

2007 Deprem yönetmeliği açısından Taşköprü İlkokul Binasının Performans Analizi yapılmış ve kiriş hasar sonuçlar aşağıda verilmiştir [Tablo 5].

Tablo 5. 2007 Performans Analizi Taşköprü İlkokulu Kiriş Hasar Yüzdeleri

\begin{tabular}{|c|c|c|c|c|c|c|c|c|c|c|c|c|c|c|c|c|}
\hline Kat & \multicolumn{4}{|c|}{$(-X)$} & \multicolumn{4}{|c|}{$(+X)$} & \multicolumn{4}{|c|}{$(-Y)$} & \multicolumn{4}{|c|}{$(+Y)$} \\
\hline No & MH & BH & IH & GB & MH & BH & IH & GB & MH & BH & IH & GB & MH & BH & IH & GB \\
\hline 2 & 100 & 0.0 & 0.0 & 0.0 & 95.7 & 0.0 & 0.0 & 4.3 & 100 & 0.0 & 0.0 & 0.0 & 100 & 0.0 & 0.0 & 0.0 \\
\hline 1 & 100 & 0.0 & 0.0 & 0.0 & 95.8 & 4.2 & 0.0 & 0.0 & 100 & 0.0 & 0.0 & 0.0 & 100 & 0.0 & 0.0 & 0.0 \\
\hline Max & 100 & & & & & 4.2 & & 4.3 & & & & & & & & \\
\hline
\end{tabular}

MH: Minimum Hasar, BH: Belirgin Hasar, IH: Ileri Hasar, GB: Göçme

2018 Deprem yönetmeliği açısından Taşköprü İlkokul Binasının Performans Analizi yapılmış ve kiriş hasar sonuçlar aşağıda verilmiştir [Tablo 6].

Tablo 6. 2018 Performans Analizi Taşköprü İlkokulu Kiriş Hasar Yüzdeleri

\begin{tabular}{|c|c|c|c|c|c|c|c|c|c|c|c|c|c|c|c|c|}
\hline $\begin{array}{c}\text { Kat } \\
\text { No }\end{array}$ & \multicolumn{4}{|c|}{$\mathbf{( - X )}$} & \multicolumn{4}{|c|}{$\mathbf{( + X )}$} & \multicolumn{4}{|c|}{$\mathbf{( - Y )}$} & \multicolumn{4}{|c|}{$\mathbf{( + Y )}$} \\
\hline 2 & SH & BH & IH & GB & SH & BH & IH & GB & SH & BH & IH & GB & SH & BH & IH & GB \\
\hline 1 & 100 & 0.0 & 0.0 & 0.0 & 100 & 0.0 & 0.0 & 0.0 & 100 & 0.0 & 0.0 & 0.0 & 100 & 0.0 & 0.0 & 0.0 \\
\hline Max & 100 & 0.0 & 0.0 & 0.0 & 100 & 0.0 & 0.0 & 0.0 & 100 & 0.0 & 0.0 & 0.0 & 100 & 0.0 & 0.0 & 0.0 \\
\hline
\end{tabular}

SH: Sinırlı Hasar, BH: Belirgin Hasar, IH: İleri Hasar, GB: Göçme

Binanın Performans analizleri yapılmış ve 2007 deprem yönetmeliğine göre kolon kesme kuvveti dağılımı ile ilgili sonuçlar aşağıda verilmiştir [Tablo 7]. 
Tablo 7. 2007 Performans Analizi Taşköprü İlkokulu Kolon Kesme Kuvveti Dă̆llımı

\begin{tabular}{|c|c|c|c|c|c|c|c|c|c|c|c|c|c|c|c|c|}
\hline \multirow{2}{*}{$\begin{array}{c}\text { Kat } \\
\text { No }\end{array}$} & \multicolumn{4}{|c|}{$(-X)$} & \multicolumn{4}{|c|}{$(+X)$} & \multicolumn{4}{|c|}{$(-Y)$} & \multicolumn{4}{|c|}{$(+Y)$} \\
\hline & SH & BH & IH & GB & SH & BH & IH & GB & SH & BH & IH & GB & SH & BH & IH & GB \\
\hline 2 & 96.0 & 3.9 & 0.1 & 0.0 & 99.6 & 0.3 & 0.0 & 0.1 & 99.9 & 0.0 & 0.1 & 0.0 & 100 & 0.0 & 0.0 & 0.0 \\
\hline 1 & 93.8 & 6.2 & 0.0 & 0.0 & 99.9 & 0.1 & 0.0 & 0.0 & 100 & 0.0 & 0.0 & 0.0 & 100 & 0.0 & 0.0 & 0.0 \\
\hline Max & & 6.2 & 0.1 & & & & & 0.1 & 100 & & & & 100 & & & \\
\hline
\end{tabular}

SH: Sinırlı Hasar, BH: Belirgin Hasar, IH: Ileri Hasar, GB: Göçme

Binanın Performans analizleri yapılmış ve 2018 deprem yönetmeliğine göre kolon kesme kuvveti dağılımı ile ilgili sonuçlar aşağıda verilmiştir [Tablo 8].

Tablo 8. 2018 Performans Analizi Taşköprü İlkokulu Kolon Kesme Kuvveti Dağılımı

\begin{tabular}{|c|c|c|c|c|c|c|c|c|c|c|c|c|c|c|c|c|}
\hline \multirow{2}{*}{$\begin{array}{l}\text { Kat } \\
\text { No }\end{array}$} & \multicolumn{4}{|c|}{$(-X)$} & \multicolumn{4}{|c|}{$(+X)$} & \multicolumn{4}{|c|}{$(-Y)$} & \multicolumn{4}{|c|}{$(+Y)$} \\
\hline & SH & BH & IH & $\mathbf{G B}$ & SH & $\mathbf{B H}$ & IH & GB & SH & BH & IH & GB & SH & $\mathbf{B H}$ & IH & GB \\
\hline 2 & 100 & 0.0 & 0.0 & 0.0 & 100 & 0.0 & 0.0 & 0.0 & 100 & 0.0 & 0.0 & 0.0 & 100 & 0.0 & 0.0 & 0.0 \\
\hline 1 & 55.3 & 44.7 & 0.0 & 0.0 & 55.3 & 44.7 & 0.0 & 0.0 & 88.6 & 11.4 & 0.0 & 0.0 & 88.6 & 11.4 & 0.0 & 0.0 \\
\hline $\operatorname{Max}$ & & 44.7 & r & & & & & 0 & . & & & & 100 & & & \\
\hline
\end{tabular}

Binanın 2007 Performans analizleri yapılmış ve alt ve üst kesimlerde minimum hasar bölgesini aşan kolonların kesme kuvveti dağılımı aşağıda verilmiştir [Tablo 9].

Tablo 9. Alt ve Üst Kesitlerde Minimum Hasar Bölgesini Aşan Kolonların Kesme Kuvveti Dă̆ılımı

\begin{tabular}{|c|c|c|c|c|c|c|c|c|}
\hline \multirow{2}{*}{$\begin{array}{c}\text { Kat } \\
\text { No }\end{array}$} & \multicolumn{2}{|c|}{$(\mathbf{- X )}$} & \multicolumn{2}{|c|}{$(+\mathbf{X})$} & \multicolumn{2}{|c|}{$(\mathbf{- Y})$} & \multicolumn{2}{|c|}{$(+\mathbf{Y})$} \\
\cline { 2 - 9 } & $\mathbf{S H}$ & $\mathbf{B H + I H + G B}$ & $\mathbf{S H}$ & $\mathbf{B H + I H + G B}$ & SH & $\mathbf{B H + I H + G B}$ & SH & $\mathbf{B H + I H + G B}$ \\
\hline 2 & 100.0 & 0.0 & 100 & 0.0 & 99.9 & 0.1 & 100 & 0.0 \\
\hline 1 & 100.0 & 0.0 & 82.2 & 17.8 & 100.0 & 0.0 & 100 & 0.0 \\
\hline Max & 100 & & & 17.8 & & & & \\
\hline
\end{tabular}

SH: Sinırlı

Hasar, BH: Belirgin Hasar, IH: Ileri Hasar, GB: Göçme

Binanın 2018 Performans analizleri yapılmış ve alt ve üst kesimlerde minimum hasar bölgesini aşan kolonların kesme kuvveti dağılımı aşağıda verilmiştir [Tablo 10].

Tablo 10. Alt ve Üst Kesitlerde Minimum Hasar Bölgesini Aşan Kolonların Kesme Kuvveti Dă̆llımı

\begin{tabular}{|c|c|c|c|c|c|c|c|c|}
\hline \multirow{2}{*}{$\begin{array}{c}\text { Kat } \\
\text { No }\end{array}$} & \multicolumn{2}{|c|}{$(-\mathbf{X})$} & \multicolumn{2}{|c|}{$(+\mathbf{X})$} & \multicolumn{2}{c|}{$\mathbf{( - Y )}$} & \multicolumn{2}{|c|}{$(+\mathbf{Y})$} \\
\cline { 2 - 8 } & SH & BH+IH+GB & SH & BH+IH+GB & SH & BH+IH+GB & SH & BH+IH+GB \\
\hline 2 & 100.0 & 0.0 & 100 & 0.0 & 100.0 & 0.0 & 100 & 0.0 \\
\hline 1 & 100.0 & 0.0 & 100 & 0.0 & 100.0 & 0.0 & 100 & 0.0 \\
\hline Max & 100 & & & 0.0 & & & & \\
\hline
\end{tabular}




\section{SONUÇ VE TARTIȘMA}

İlkokul binası; binanın mimari özellikleri, binada kullanılan beton ve donatı özellikleri, binanın temeli, statik özellikleri vb. açılardan çok yönlü olarak değerlendirilmiştir. 2007 Deprem Yönetmeliğinin 3.2.5.1. maddesine göre "Deprem bölgelerinde yapılacak tüm betonarme binalarda C20'den daha düşük dayanımlı beton kullanılamaz" denilmektedir. Ayrıca 2018 Deprem Yönetmeliğine. 11.2.12 maddesinde "Donatısız yığma bina, donatılı yığma bina, kuşatılmış yığma bina ve donatılı panel sistemli binaların betonarme bileşenlerinde beton sınıfı en az C25 olacaktır denilmektedir. Bu açıdan değerlendirildiğinde söz konusu binanın beton basınç dayanımının yönetmelikte tanımlanan basınç dayanımı değerinin altında olduğu anlaşılmaktadır. Bu nedenle 2007 ve 2018 Deprem yönetmeliklerine göre binanın güçlendirme projelerinin hazırlanması ve taşıyıcı elemanlarda yetersiz olan taşıyıcı elemanların yeniden boyutlandırılmasına ihtiyaç duyulmaktadır. İncelenen binada Zeminin Emniyetli Taşıma gücü değerinin emniyetli bölgede kalmak amacıyla qem $=0.50 \mathrm{~kg} / \mathrm{cm}^{2}$ olarak alınmasının daha uygun olacağı düşünülmektedir.

Zemin yatak katsayıs1 ise 500-1000 ton/m3 önerilmiş olmakla birlikte güvenli kesimde kalabilmek amacıyla zeminin yatak katsayısının da 500 ton $/ \mathrm{m}^{3}$ olarak alınmasının uygun olacağı düşünülmektedir. Zemin Etüt Raporunda, incelenen binalarda zeminin; Deprem Bölgelerinde Yapılacak Yapılar Hakkında Yönetmeliğe göre D Zemin Grubunda ve Z4 Yerel Zemin Sınıfında olduğu belirtilmiş ancak zeminin heterojen özellikte olması da dikkate alınarak yerinde yapılacak başka incelemeler sonucunda belirlenecek değerlere göre nihai karar verilebileceği kanaatine varılmıştır.

Yeni Taşköprü İlk Okulu binasının zemininde 3,0 m derinlikte YSS olduğu zemin etüt raporundan anlaşılmakta olup yapılacak çalışmalarda sıvılaşma vb. özel durumlar açısından gerekli tedbirlerin alınması gerektiği değerlendirilmektedir.

\section{KAYNAKLAR}

1] http://www.csb.gov.tr/dosyalar/images/file/guc.pdf

[2] https://www.imo.org.tr/resimler/dosya_ekler/b1839dc54405b85_ek.pdf?dergi=139

[3] STA4-V14.1 "Structural Analysis for Computer Aided Design" user guide.

[4] http://web.iku.edu.tr/ ecoskun/Guclendirme.pdf

[5] http://www.tdmd.org.tr/TR/Genel/pdf2015/TDMSK_162.pdf

[6] M.Arıkan, H.Sucuoğlu, G. Macit, "Economic assesment of the sesimic retrofitting of low-cost apartment buildings," Journal of Earthquake Engineering, 2005.(9,4, p.p.577-584).

[7] Deprem Bölgelerinde Yapılacak Binalar Hakkında Yönetmelik, 2007.

[8] Deprem Bölgelerinde Yapılacak Binalar Hakkında Yönetmelik, 2018.

[9] H. Sucuoğlu, "Mevcut yapılarda durum saptaması, Bizim büro basımevi, Ankara, 2008. 
[10] T. Tankut, E. Ersoy, G. Özcebe ve E. Canbay, "Betonarme Yapıların Onarımı ve Güçlendirilmesi için Kullanılan Yöntemler, Bizim Büro Basımevi, Ankara.

[11] A. Ergün, G. Kürklü, “Depremlerde bina performanslarının DBYBHY 2007’e göre doğrusal elastik hesap yöntemleri ile belirlenmesinde malzeme sınıfının değişiminin incelenmesi," Uluslararası Deprem Mühendisliğinde Gelişmeler Sempozyumu, 24-26 ekim 2007, Isparta- Antalya, 576-586.

[12] A. Ergün, G. Kürklü, “Mevcut Betonarme bir Binanın DBYBHY 2007’e göre Doğrusal Elastik Hesap Yöntemleri ile Değerlendirme ve Güçlendirme Uygulaması,” Sempozyumu, 1-2 Ekim 2009, Sakarya.

[13] http://fenbildergi.aku.edu.tr/1202/025601(1-11)

[14] F.Altun, H.B. Kara, E. Uncuoğlu, O.Karahan "Earthquake Damages in Reinforced -Concrete Structures and Retrofitting Work on A6 Storey Building “Ankara 2003, 16,say1 2 sayfa, 309-318.

[15] A. Nuhoğlu, B. Arısoy, R. Taşçı, “Izmir'de Okulların Yapısal Özelliklerinin Araştırılması ve Deprem Davranışlarının Değerlendirilmesi” İzmir Afet Riskini Azaltma Sempozyumu, İzmir, 2009.

[16] S. Mısır, Ö. Özçelik, S. Kahraman "Kolon-kiriş Birleşimlerinin Davranışlarının Değerlendirilmesi ve Konu Üzerine Yürütülen Deneysel Çalışmalar”, İMO İzmir Şubesi Haber Bülteni, y1l:244, sayı:146 2009, İzmir.

[17] T. Kap, E. Özgan, M.M. Uzunoğlu, "Betonarme bir Okul Binasının 2007 Deprem Yönetmeliğine göre Performans Analizi," Illeri Teknoloji Bilimleri Dergisi, c. 6, s. 4, ss.1-10, 2017. 